\title{
Religiosity, Spirituality, and Life Satisfaction in Relation to Teachers' Service Quality
}

\author{
JIMMY D. BUCAR \\ http://orcid.org/0000-0001-7610-5405 \\ pms.jimmy@gmail.com \\ JEROME M. MAGALLEN \\ http://orcid.org/0000-0002-8793-0897 \\ jmmagallen@universityofbohol.edu.ph
}

\begin{abstract}
Religiosity in this study pertains to five dimensions, namely: public practice, private practice, religious experience, ideology, and intellectual dimensions. Service quality is defined as an overall judgment similar to attitude towards the service and generally accepted as an antecedent of overall customer satisfaction. This study aimed to ascertain if religiosity, spirituality, and life satisfaction are predictors of service quality among 15 faculty members in Cawayanan National High School, Tubigon East District, Division of Bohol, Philippines, who held permanent teaching positions as of S.Y. 2015 - 2016. It utilized descriptive-correlational research design through survey method. The results of the findings revealed that the respondents were highly religious in four areas of religiosity: ideology, public practice, private practice, and religious experience as measured through CRS-15. They possessed High Spirituality level and felt that they were "Very Close" to God. They also obtained Average Satisfaction in life as measured in the SWLS. The respondents showed a satisfactory level of
\end{abstract}


service quality in the five areas of service quality (Reliability, Assurance, Tangibles, Empathy, and Responsiveness). Recommendations were proposed to translate the respondents' high religiosity and spirituality levels into selfless service and commitment.

Keywords: Social Science, religiosity, spirituality, life satisfaction, quantitative, Pearson Product Moment Correlation, Philippines, Asia.

\section{INTRODUCTION}

According to the Education for All Global Monitoring Report 2005 by (United Nations Educational, Scientific, and Cultural Organization) UNESCO, the quality of teaching and learning provided by a school can have a significant impact on students' attendance and retention. For parents, sending their children to school is influenced by their perception of service quality rendered by the school in general, whether it is worth the time and cost for their children and themselves as well. Based on the report of the UNESCO in 2013, the Philippines is ranked fifth with regards to dropout rates (Rigor, 2015). Since teachers play a strategic role in the provision of quality education in the country, their role as primary service providers in every public institution must be taken into consideration to lessen the burgeoning student dropouts in the country (Durban and Catalan, 2012).

A research study conducted by Voluntary Service Overseas (2002) in developing countries, in which the Philippines is one of them, found out that teachers' motivation to teach well was fragile and declining. The report also noted that teacher's motivation, performance and education quality have strong links. Other studies have shown as well the impact of teachers motivation on the quality of instruction. Where teachers are highly motivated to perform their duties, the quality of instruction is high. Where they are poorly motivated, the quality of instruction suffers. This calls for a study that will address the declining passion of teachers to perform their best as a reflection of their social responsibility.

In the study of Osman-Gani and his colleagues in Kuala Lumpur, Malaysia, they found out that religiosity, spirituality, personal values and commitment correlate with employees' performance (Osman-Gani Hashim, \& Ismail, 2010). It finds support in the study of Karakas (2010) where he stressed out three important influences of spirituality to employees quality of work in an organization. First, spirituality significantly influenced 
the employees' psychological well-being by boosting their morale, commitment, and productivity by lessening the work pressure and burnout. Second, it provides a deeper sense of meaning and purpose in one's work and lastly, it gives a sense of community and connectedness among employees. Seeing the potential benefits of spirituality to employees, Karakas recommended incorporating spirituality in organizations (Karakas, 2010). Furthermore, life satisfaction is also listed as one of the predictors of teachers' work quality (Duckworth, Quinn, \& Seligman, 2009) since happy and satisfied teachers are productive workers (Usop, Askandar, Langguyuan-Kadtong, \& Usop, 2013).

Cognizant of the role of teaching quality as a school-based factor in student achievement (McCaffrey, Lockwood, Koretz, \& Hamilton, 2003; Hightower, Delgado, Lloyd, Wittenstein, Sellers \& Swanson, 2011) and the potential link between religiosity, spirituality and life satisfaction to teachers' service quality as shown in previous research conducted abroad, a local study is hereby necessary. Interestingly, there are already existing local studies about religiosity and spirituality showing the religious nature among Filipinos (e.g. Batara, 2015); however, the focus was more on teenagers. To date, there is a paucity of studies indexed in the Google Scholar which explore the impact of religiosity, spirituality, and life satisfaction to the teaching profession.

The researchers took the challenge of conducting this pioneering study in the province, particularly in Cawayanan National High School, Cawayanan, Tubigon, Bohol, where one of the researchers is currently employed as Values Education Teacher and Guidance Counselor Designate. Furthermore, this study also sought to validate the assumption that religious and highly spiritual people are good workers because they believe in divine accountability as one of the fundamental tenets of Christianity. As spiritually moved individuals, teachers are taught that their profession is a sacred calling which means their job is not merely work for a pay but a special vocation sanctioned by the Divine. This is the research gap that the researchers would like to address.

Religiosity and Spirituality are related concepts commonly confounded and used interchangeably by several researchers (Miller and Martin, 1988; George, Larson, Koenig, \& McCullough, 2000; Fisher, 2010). Several researchers attempted to differentiate these terms, but they did not arrive at an agreed-upon definition. According to Holdcroft (2006), there were two reasons why there is a difficulty in defining the word "religiosity." 
First, the inaccuracy of the English language and second, the overlapping concept of religiosity in several fields interpreting it from a different point of views (e.g., theological, psychological).

Several researchers in the past such as Nickles (2011) and Fryback and Reinert (1999) often thought of religiosity and spirituality as the same terminologies. However, researchers today agree they are not the same concepts. Although both terms touch transcendental realities or the metaphysical aspects of life (Yalung, 2010), they differ with regards to scope and level of experience. Religiosity is understood in the context of social level experience while spirituality is on an individual level experience (Nickles, 2011).

Religiosity came from the word religion - a term derived from a Latin word " religare," meaning "to bind together" (Ryan, 2006; Yalung, 2010) or communion between a person and a higher being (Batara, 2015). According to Koenig (2012), religion involves beliefs, practices, and rituals related to the transcendent, where the transcendent is God, Allah, HaShem, or a Higher Power in Western religious traditions. The Merriam-Webster Dictionary defines religion as "a personal set or institutionalized system of religious attitudes, beliefs, and practices". Religiosity pertains to the condition of being religious or attachment to any belief system as measured by its intensity, salience, importance or centrality in the personality of an individual (Huber and Huber, 2012).

Religiosity has five dimensions, namely: public practice, private practice, religious experience, ideology, and intellectual dimensions. Public practice pertains to outward engagement and participation in various rituals and practices prescribed by a religious community. It is usually measured by the frequency of attendance in various religious services. Private practice is the expression of individual devotion to God through solitary prayer and meditation. Religious experience pertains to personal encounter and emotional experience with a particular deity, and it is expressed through religious feelings and emotions (Stark and Glock, 1968). The ideology dimension refers to one's belief of the existence and ontology of a Supreme Being and his relationship to humankind. Lastly, the intellectual dimension refers to one's knowledge about one's belief system and practices. It also involves cognitive ability to interpret, explain and defend one's religion (Huber and Huber, 2012).

On the other hand, spirituality is a human experience that seeks to 
transcend self and find meaning and purpose through connection with others, nature, and a Supreme Being, which may or may not involve religious structures or traditions (Buck, 2006). In essence, religiosity is always associated with a social and institutional belief while spirituality is more on the personal aspect of the search for the transcendent with or without the presence of any religious organization. In other words, one can be spiritual even without any religious affiliation.

Life satisfaction is one of the sub-constructs of subjective well-being along with Affect Balance. The Affect Balance measures the affective side of subjective well-being while life satisfaction measures the cognitive aspect or the global judgment of one's life. The life satisfaction construct is measured through the Satisfaction with Life Scale developed by Edward Diener, which consists of five questions measuring global judgment of one's life satisfaction. This is answered on a 7-point Likert scale ranging from "strongly agree" to "strongly disagree" (Diener, 1985; Diener, 2000).

Service quality is defined as an overall judgment similar to attitude towards the service and generally accepted as an antecedent of overall customer satisfaction (Parasuraman, Zeithaml, and Berry, 1985). It is the disparity between what customers expect from the service provider and their perception of the service rendered (Zeithaml, Parasuraman, and Berry, 1990). This is computed by getting the variance between customers' expectation of the service and their perception of the service. If their expectation is higher than the actual performance of the service providers, then it is perceived as less satisfactory. In this study, however, Service quality is measured from the perspective of the teachers as service providers to their students. Their service quality is measured using a modified version of ServQual Model also known as RATER Scale. RATER stands for Reliability, Assurance, Tangibles, Empathy and Responsiveness.

\section{METHODOLOGY}

This is descriptive-correlational research utilizing three standardized tools that have been validated in various studies and a self-constructed questionnaire patterned after the RATER Model of Parasuraman and company. These questionnaires are the (1) Centrality of Religiosity Scale (CRS) which measures the respondents' religiosity level; (2) Daily Spiritual Experience Scale (DSES) to measure spirituality; (3) Satisfaction With Life Scale (SWLS) which is designed to measure global cognitive judgements 
of one's life satisfaction (Diener et al, 1985); and (4) Service Quality Scale (ServQual) which measures the perceived service quality rendered by the respondents.

The respondents of this study were the 15 teachers of Cawayanan National High School (CNHS), Cawayanan, Tubigon, Bohol, who hold permanent teaching positions as of S.Y. 2015 - 2016. CNHS is under the Tubigon East District, one of the two districts in the municipality. It was established in the year 1993 in response to the call for a public high school in the community.

To get the desired information of this study, the researchers used with permission three standardized questionnaires and one selfconstructed questionnaire patterned after the ServQual Model. The Centrality of Religiosity Scale (CRS-15) measures the respondents' religiosity level (Huber \& Huber, 2012) through five (5) dimensions, namely: public practice, private practice, religious experience, ideology, and intellectual dimensions. Responses are measured on a 5-point Likert scale, with higher scores indicating a high level of religiosity. Scores are computed through computing the means for each dimension and also the overall mean which represents religiosity level (Huber and Huber, 2012).

The Daily Spiritual Experience Scale (DSE) was used to measure the respondents' ordinary and personal spiritual experience in daily life and perception of the transcendent, be it God or the divine (Underwood and Teresi, 2002). DSES is a 16-item measure of the responses measured on a 6-point Likert scale. Items 1 to 15 is scored using a 6-point scale whereas item 16 on a 4-point scale. The first 15 items are scored continuously, and item 16 is scored separately. Reliability coefficients of DSES were high (Underwood \& Teresi, 2002).

The third instrument is the Satisfaction With Life Scale (SWLS) of Diener (1985), a 5-item scale designed to measure global cognitive judgments of one's life satisfaction. In this scale, the respondents indicate how much they agree or disagree with each of the 5 items using a 7-point scale that ranges from 7 strongly agree to 1 strongly disagree (Diener, 1985).

Lastly, the Service Quality Scale (ServQual) which is patterned after the ServQual Model (or RATER Model) originally developed by Valarie Zeithaml, Parasuraman, and Leonard was used to measure the respondents' self-rated service quality in the RATER Dimensions. RATER stands for Reliability, Responsiveness, Assurance, Empathy, and Tangibles. In this study, the Service Quality Scale is composed of 42 questions distributed in the following dimensions: Reliability (11 Items), Assurance (6 Items), 
Tangibles (6 Items), Empathy (9 Items), and Responsiveness (10 Items). It is answered by a four-point Likert scale: Strongly Disagree (1), Disagree (2), Agree (3), Strongly Agree (4) Agree.

\section{RESULTS AND DISCUSSIONS}

\section{Religiosity of the Respondents}

Table 1 shows the respondents' level of religiosity in the following dimensions: intellectual, ideology, public practice, private practice, religious experience.

Table 1. Respondents' level of religiosity

\begin{tabular}{|l|c|c|c|}
\hline \multicolumn{1}{|c|}{ Dimension } & WM & Interpretation & Rank \\
\hline Intellectual Dimension & 3.71 & Religious & 5 \\
\hline Ideology & 4.4 & Highly Religious & 2 \\
\hline Public Practice & 4.22 & Highly Religious & 3 \\
\hline Private Practice & 4.64 & Highly Religious & 1 \\
\hline Religious Experience & 4.13 & Highly Religious & 4 \\
\hline Overall Religiosity & 4.21 & Highly Religious & \\
\hline
\end{tabular}

\section{Legend:}

Arbitrary Scale

$\begin{array}{ll}\text { Scale } & \text { Interpretation } \\ 4.0-5.0 & \text { Highly Religious } \\ 2.1-3.9 & \text { Religious } \\ 1.0-2.0 & \text { Not Religious }\end{array}$

As depicted in table 1, the respondents were highly religious except in the intellectual dimension where they only obtained a weighted mean of 3.71 interpreted as "Religious". Since the Intellectual Dimension deals with the expectation that a person will be oriented and knowledgeable about the basic tenets of his faith and sacred scriptures (Holdcroft, 2006, it implies that the respondents were not very updated with latest religious issues and not so knowledgeable about their church teachings. Jocano (1967 opined this is due to a firm reliance on concrete religious activities rather than on personal quest which is common among Filipino Catholics.

The table also depicted that they obtained the highest score of 4.64 (Highly Religious) in the private practice dimension. It implies that despite lesser knowledge of church doctrines, they exhibited sincere devotion to God through personal prayer and meditation. They were highly religious 
which coincides with the studies of various researchers (Pe-Pua and Protacio-Marcelino, 2000; Tigno, 2007; Casiňo, 2009; Figer et al., 2010; Abad, 2001) who emphasized the strong reliance of Filipinos on religion as a source of strength, hope, and courage. It also validated the postulation that religion is an integral part of human existence (Zuckerman, 2005) and Viktor Frankl's thesis that religion is an inherent latent characteristic of humanity and serves as man's mode of knowing the meaning of his existence (Russell, 2007).

\section{Spirituality of the Respondents}

Spirituality refers to a particular quality which goes beyond religiosity and involves striving for inspiration, meaning, and purpose irrespective of a belief in any Divine Being. It is focused on connecting with others and contains three main components: connection to someone or something beyond oneself, sense of compassion for others, and desire to contribute to the good of others (Blando, 2006). Table 2 illustrates the level of spirituality and felt closeness to God of the respondents.

Table 2. Respondents' level of spirituality

\begin{tabular}{|l|c|c|c|}
\hline \multicolumn{1}{|c|}{ Dimensions } & WM & Interpretation & Rank \\
\hline Connection with the Transcendent & 4.97 & High & 5 \\
\hline Transcendent Sense of Self & 4.60 & High & 9 \\
\hline Sense of Support from the Transcendent & 4.67 & High & 8 \\
\hline Sense of Wholeness/Internal Integration & 4.73 & High & 7 \\
\hline Inspiration \& Discernment & 5.00 & High & 3.5 \\
\hline Perceived Love & 5.17 & Very High & 2 \\
\hline Sense of Awe & 4.93 & High & 6 \\
\hline Sense of Gratitude & 5.53 & Very High & 1 \\
\hline Sense of Compassion & 3.93 & Average & 11 \\
\hline Sense of Mercy & 4.00 & Average & 10 \\
\hline Longing for the Transcendent & 5.00 & High & 3.5 \\
\hline & 4.80 & High & \\
\hline Felt Closeness to God & 2.67 & Very Close & \\
\hline
\end{tabular}


Parameters:

Level of Spirituality

Arbitrary Scale Interpretation

$5.17 \quad-\quad 6.00 \quad \operatorname{Very} \operatorname{High}(\mathrm{VH})$

4.34 - $5.16 \quad \operatorname{High}(H)$

3.50 - $4.33 \quad$ Average $(A)$

$2.66 \quad-3.49 \quad$ Below Average (BA)

$1.83-2,65 \quad \operatorname{Low}(L)$

$1.00-1.82 \quad \operatorname{Very} \operatorname{Low}(V L)$
Level of Closeness

Arbitrary Scale Interpretation

$3.25 \quad$ - $4.00 \quad$ As close as possible

2.50 - $3.24 \quad$ Very Close

$1.75 \quad-2.49 \quad$ Somewhat Close

$1.00-1.74 \quad$ Not at all

Table 2 depicts that the respondents possessed "Very High Spirituality" as to their sense of gratitude and perceived love while they only obtained "Average Spirituality" concerning their sense of compassion and mercy. The other aspects were rated "High." Their overall rating was 4.8 which means they possessed a "high level of spirituality" indicating that they experience spiritual connection many times a day, every day and most days. It also shows that they possessed spiritual transcendence "everyday" of their lives. Moreover, concerning the degree of closeness to God, the respondents felt they were very intimate to God as evident with their composite score of $\mathbf{2 . 6 7}$ which has an interpretation of "Very Close."

The result conforms to the study of Abad (2001) concerning the religious and spiritual nature of Filipinos. Spirituality is embedded in their psyche and finds unique expression in their confrontative surface value "Bahala Na" (i.e., leave it up to "Bathala" or God). Although it has both positive and negative impact among Filipinos, nonetheless it emphasizes Filipino's natural inclination towards a particular divinity. This inclination towards God substantiates the thesis that "spirituality is a robust, universal human quality" (Piedmont, 2007).

\section{Life Satisfaction of the Respondents}

Life Satisfaction pertains to a person's evaluation of his life, and he or she feels where it is going in the future. It is one of the measures and components of psychological well-being. Table 3 presents the respondents' life satisfaction index as measured using the Satisfaction with Life Scale (SWLS) developed by Ed Diener. 
Table 3. Respondents' level of life satisfaction

\begin{tabular}{|l|c|c|}
\hline \multicolumn{1}{|c|}{ Items } & WM & Description \\
\hline 1. In most ways my life is close to my ideal. & 5.00 & High \\
\hline 2. The conditions of my life are excellent. & 4.73 & Average \\
\hline 3. I am satisfied with my life. & 5.33 & High \\
\hline 4. So far I have gotten the important things I want in life. & 4.93 & Average \\
\hline 5. If I could live my life over, I would change almost nothing. & 4.73 & Average \\
\hline Composite Mean & $\mathbf{4 . 9 5}$ & Average \\
\hline
\end{tabular}

Legend (Diener et al., 2013):

\begin{tabular}{|c|c|c|c|c|}
\hline \multicolumn{3}{|c|}{ Arbitary Scale } & Description & Meaning \\
\hline 6.00 & - & 7.00 & Very High & Highly Satisfied with Life \\
\hline 5.00 & - & 5.99 & High & Satisfied with life \\
\hline 4.00 & - & 4.99 & Average & Slightly satisfied with life \\
\hline 3.00 & - & 3.99 & Slightly Below Average & Slightly dissatisfied with life \\
\hline 2.00 & - & 2.99 & Low & Dissatisfied with life \\
\hline 1.00 & - & 1.99 & Very Low & Extremely Dissatisfied with life \\
\hline
\end{tabular}

Table 3 revealed that the respondents rated high with regards to the degree of closeness of their actual life to ideal and their satisfaction to their personal life. They only obtained an "Average" rating in their assessment of the conditions of their lives; getting the important things they want in life as well as changing nothing if given a chance to live again in this life. Overall, they obtained a composite score of 4.95 indicating they were "Slightly Satisfied" with their lives as in general. According to Diener et al. (1985) possessing "Average Satisfaction Index" in the SWLS indicates that a person has small but significant problems in several areas of his life or has many areas that are doing fine but one area that represents a substantial challenge for him.

The Life Satisfaction Index of the teacher-respondents coincides with the survey of Social Weather Stations (SWS) that majority or 81 percent of Filipinos who are in Class $A B C$ are satisfied in their lives despite life's social conditions and unstable economy of the country. It also coincides with the study of Jaafar et al., (2009) which named Filipinos as satisfied individuals. It verified the cross-sectional study of Diener, Diener, and Diener (1995) that people from poor or developing 
countries possessed only average life satisfaction index. Furthermore, it echoed the idea that most people in the world are happy beings despite challenging conditions in their lives (Diener and Diener, 1996).

\section{Service Quality of the Respondents}

In this study, service quality pertains to the respondents' perception of the adequacy and quality of service they render to students as their clients or customers. It is the extent to which they perform their duties as teacher-facilitators. Service Quality is measured using the RATER Model of Parasuraman and colleagues. RATER stands for the five dimensions of service quality, namely: (1) reliability, (2) assurance, (3) tangibles, (4) empathy, and (5) responsiveness.

Table 4. Level of service quality in reliability dimension

\begin{tabular}{|l|c|l|c|}
\hline \multicolumn{1}{|c|}{ RELIABILITY Dimension } & WM & \multicolumn{1}{|c|}{ Description } & Rank \\
\hline I am punctual in reporting to class. & 3.07 & Satisfactory & 5.5 \\
\hline I give enough volume/number of exercises to my students. & 3.13 & Satisfactory & 4 \\
\hline I give fair, honest \& accurate grades my students deserve. & 3.20 & Satisfactory & 2.5 \\
\hline I treat my students in a fair \& equitable manner. & 3.27 & Very Satisfactory & 1 \\
\hline $\begin{array}{l}\text { I come to class ready as pre-planned in my lesson log or } \\
\text { lesson plan. }\end{array}$ & 2.87 & Satisfactory & 9 \\
\hline I have an error free record of my students. & 2.80 & Satisfactory & 10 \\
\hline I am able to finish all the competencies for every quarter & 2.07 & Unsatisfactory & 11 \\
\hline I establish procedures \& rules that enhance learning. & 2.93 & Satisfactory & 8 \\
\hline I give tests/quizzes at the time promised. & 3.00 & Satisfactory & 7 \\
\hline I submit students' grades punctually. & 3.20 & Satisfactory & 2.5 \\
\hline $\begin{array}{l}\text { I demonstrate a sound understanding of technology } \\
\text { operations \& concepts. }\end{array}$ & 3.07 & Satisfactory & 5.5 \\
\hline Composite Mean & $\mathbf{2 . 9 6}$ & Satisfactory & \\
\hline
\end{tabular}

\section{Parameters:}

Arbitrary Scale Description

$\begin{array}{llll}3.25 & - & 4.00 & \text { Very Satisfactory }(V S) \\ 2.50 & - & 3.24 & \text { Satisfactory }(S) \\ 1.75 & - & 2.49 & \text { Unsatisfactory }(U) \\ 1.00 & - & 1.74 & \text { Very Unsatisfactory }(V U)\end{array}$


Table 4 clearly shows the rating of the respondents in the different aspects of reliability dimension. The composite mean in this dimension was $\mathbf{2 . 9 6}$ which fell in the satisfactory level of service quality; however, there are two items with extreme scores. They obtained "Very Satisfactory" rating with regards to treating their students in fair and equitable manner. On the other hand, they only obtained "Unsatisfactory" rating with regards to finishing all the required competencies for every quarter. Satisfactory performance in this dimension indicates that the teachers perceived themselves as highly reliable or consistent most especially in terms of fairness and justice. Based on the personal interview, they only fell short in accomplishing the required competencies because of several interruptions in their classes such as extra-curricular activities, seminars, and paper works which somehow hamper their intention to reach their targets.

Table 5. Level of service quality in assurance dimension

\begin{tabular}{|l|c|l|c|}
\hline \multicolumn{1}{|c|}{ ASSURANCE Dimension } & WM & \multicolumn{1}{|c|}{ Description } & Rank \\
\hline $\begin{array}{l}\text { I am knowledgeable and competent enough to teach } \\
\text { the students. }\end{array}$ & 3.00 & Satisfactory & 4 \\
\hline $\begin{array}{l}\text { I am polite and courteous at all times in dealing with } \\
\text { students. }\end{array}$ & 2.93 & Satisfactory & 5.5 \\
\hline I instil confidence in my students. & 2.93 & Satisfactory & 5.5 \\
\hline $\begin{array}{l}\text { I always assure the students that they are safe \& } \\
\text { secured under my care. }\end{array}$ & 3.20 & Satisfactory & 1 \\
\hline $\begin{array}{l}\text { I provide assurance for students' emotional support } \\
\text { in my class. }\end{array}$ & 3.07 & Satisfactory & 2.5 \\
\hline $\begin{array}{l}\text { I create \& maintain an environment that supports } \\
\text { learning. }\end{array}$ & 3.07 & Satisfactory & 2.5 \\
\hline Composite Mean & $\mathbf{3 . 0 3}$ & Satisfactory & \\
\hline
\end{tabular}

The data presented in the table showed the respondents possessed satisfactory performance in the assurance dimension as evident by their composite score of $\mathbf{3 . 0 3}$ which had an interpretation of "Satisfactory". It means that the respondents perceived themselves as trustworthy teachers because they possessed the necessary skills, pedagogical knowledge, and ability to provide the students' psychological, spiritual, social, and emotional needs. 
Table 6. Level of service quality in tangibles dimension

\begin{tabular}{|c|c|c|c|}
\hline TANGIBLES DIMENSION & WM & Description & Rank \\
\hline I am well-dressed/well-groomed when I enter to class. & 3.13 & Satisfactory & 2 \\
\hline $\begin{array}{l}\text { I have the necessary materials, supplies \& equipment } \\
\text { (e.g. chalk, testing materials) at the start of my lesson } \\
\text { or instructional activity. }\end{array}$ & 3.00 & Satisfactory & 3.5 \\
\hline $\begin{array}{l}\text { I provide appropriate notes/handouts as background } \\
\text { materials for my students. }\end{array}$ & 3.20 & Satisfactory & 1 \\
\hline $\begin{array}{l}\text { I use relevant and timely teaching aids to capture the } \\
\text { students' attention. }\end{array}$ & 3.00 & Satisfactory & 3.5 \\
\hline $\begin{array}{l}\text { I give rubrics or criteria sheet before the start of any } \\
\text { performance task. }\end{array}$ & 2.93 & Satisfactory & 5.5 \\
\hline $\begin{array}{l}\text { I prepare evaluation/appraisal sheet for my students } \\
\text { every grading period to assess my teaching } \\
\text { effectiveness. }\end{array}$ & 2.93 & Satisfactory & 5.5 \\
\hline Composite Mean & 3.03 & Satisfactory & \\
\hline
\end{tabular}

Table 6 presents that the respondents garnered a composite mean of 3.03 which fell under "Satisfactory Level" in the tangibles dimension. It means they perceived themselves as teachers equipped with the necessities in facilitating such as learning materials (e.g. CG, DLP) and other tangibles that enhanced learning such as physical outlook and positive gestures.

\begin{tabular}{|l|c|c|c|}
\hline \multicolumn{1}{|c|}{ Empathy Dimension } & WM & Description & Rank \\
\hline $\begin{array}{l}\text { I consider teaching as a divine vocation; therefore, I } \\
\text { am accountable to God and to my students. }\end{array}$ & 3.33 & Satisfactory & 1 \\
\hline $\begin{array}{l}\text { I am courteous and thoughtful of my students' personal } \\
\text { concerns. }\end{array}$ & 3.07 & Satisfactory & 5 \\
\hline $\begin{array}{l}\text { I show cordial interest in helping students solve their } \\
\text { academic problems. }\end{array}$ & 2.93 & Satisfactory & 7.5 \\
\hline $\begin{array}{l}\text { I am keen to my students' psychological (i.e. cognitive } \\
\text { \& affective) needs. }\end{array}$ & 3.13 & Satisfactory & 3 \\
\hline $\begin{array}{l}\text { I keep the students' interest and learning styles at } \\
\text { heart. }\end{array}$ & 2.93 & Satisfactory & 7.5 \\
\hline I give individual/personal attention to my students. & 2.80 & Satisfactory & 9 \\
\hline $\begin{array}{l}\text { I put myself in the shoes of my students by understand- } \\
\text { ing their capacities and psychosocial background. }\end{array}$ & 3.07 & Satisfactory & 5 \\
\hline
\end{tabular}




\begin{tabular}{|l|c|c|c|}
\hline $\begin{array}{l}\text { I observe confidentiality when students disclosed sen- } \\
\text { sitive information to me }\end{array}$ & 3.20 & Satisfactory & 2 \\
\hline $\begin{array}{l}\text { I use positive (e.g. praises) and negative reinforcement } \\
\text { appropriately. }\end{array}$ & 3.07 & Satisfactory & 5 \\
\hline Composite Mean & $\mathbf{3 . 0 6}$ & Satisfactory & \\
\hline
\end{tabular}

Table 7 clearly shows the responses of the respondents in the empathy dimension. As depicted, the respondents got a satisfactory rating in all the items listed in this domain and obtained a composite mean of $\mathbf{3 . 0 6}$ with an interpretation of "Satisfactory." It simply means that they possess empathy or unconditional positive regard which enabled them to act not only as paid mentors, but also as spiritual guides with a mission to educate the learners in their totality.

Table 8. Level of service quality in responsiveness dimension

\begin{tabular}{|c|c|c|c|}
\hline Responsiveness Dimension & WM & Description & Rank \\
\hline I readily respond to my students' concerns/needs & 3.07 & Satisfactory & 2 \\
\hline I am constantly willing to assist my students. & 3.07 & Satisfactory & 2 \\
\hline $\begin{array}{l}\text { I give adequate time for students to understand the } \\
\text { lesson. }\end{array}$ & 3.07 & Satisfactory & 2 \\
\hline $\begin{array}{l}\text { I give prompt attention to my students in areas other } \\
\text { than studies. }\end{array}$ & 3.00 & Satisfactory & 5 \\
\hline My teaching pedagogy is psychologically appealing. & 2.93 & Satisfactory & 8 \\
\hline I give on time response to students' queries. & 3.00 & Satisfactory & 5 \\
\hline $\begin{array}{l}\text { I help my students find meaning in their lives as } \\
\text { students. }\end{array}$ & 3.00 & Satisfactory & 5 \\
\hline I help my students in goal setting. & 2.93 & Satisfactory & 8 \\
\hline $\begin{array}{l}\text { I plan and design effective learning environment and } \\
\text { experiences with the support of } 21^{\text {st }} \text { century technol- } \\
\text { ogy. }\end{array}$ & 2.87 & Satisfactory & 10 \\
\hline $\begin{array}{l}\text { I apply information technology to facilitate a variety of } \\
\text { effective assessment and evaluation strategies. }\end{array}$ & 2.93 & Satisfactory & 8 \\
\hline Composite Mean & 2.99 & Satisfactory & \\
\hline
\end{tabular}

With a composite mean of $\mathbf{2 . 9 9}$, the respondents' service quality in the responsiveness dimension showed a consistent pattern with that of the other dimensions. The respondents in this dimension were rated "Satisfactory" which means they are responsive to the learning and psychosocial needs of the learners as evidently shown by their prompt response to students' concerns and application of 21 st century technology 
in facilitating a variety of effective assessment and evaluation strategies.

Table 9. Overall level of service quality

\begin{tabular}{|c|c|c|c|}
\hline Dimensions & WM & Description & Rank \\
\hline Reliability & 2.96 & Satisfactory & 5 \\
\hline Assurance & 3.03 & Satisfactory & 2.5 \\
\hline Tangibles & 3.03 & Satisfactory & 2.5 \\
\hline Empathy & 3.06 & Satisfactory & 1 \\
\hline Responsiveness & 2.99 & Satisfactory & 4 \\
\hline Grand Mean & 3.01 & Satisfactory & \\
\hline
\end{tabular}

Table 9 depicts the respondent's perceived level of service quality in the five dimensions of service quality. They obtained the highest rating in the empathy dimension, followed by assurance and tangibles, responsiveness and lastly reliability. They obtained a grand mean of $\mathbf{3 . 0 1}$ which is interpreted as Satisfactory. The result indicates that the Cawayanan National High School's service quality was good; however, it has the potential to get even better provided some areas with low ratings is improved.

The attainment of this level animates the main thrust of the Department of Education of providing quality education to all its stakeholders. It is a visible indicator of the school's commitment to excellence. Such commitment corresponds to one of the five key themes in Global Education (right to education, equity, inclusion, quality education and lifelong learning) declared in the World Education Forum 2015 at Incheon, South Korea. The Incheon Declaration (2015) stressed out the crucial role of teachers in providing quality education to all people.

Table 10. Relationship between religiosity and spirituality

\begin{tabular}{|c|c|c|c|c|c|}
\hline $\begin{array}{c}\text { Pearson } \mathbf{r} \\
\text { value }\end{array}$ & $\begin{array}{c}\text { Critical Value } \\
\text { of } \mathbf{r}\end{array}$ & Df & $\begin{array}{c}\text { Level of } \\
\text { significance }\end{array}$ & Result & Decision \\
\hline 0.422426 & 0.5139 & 13 & 0.05 & Insignificant & Ho: Accept \\
\hline
\end{tabular}

Correlation of Religiosity and Spirituality. There was no correlation between the respondents' religiosity and spirituality as clearly demonstrated in the Pearson computation. The $r$ value $(0.422426)$ was lower than its critical value $(0.5139)$ at $13 \mathrm{df}$ at 0.05 confidence level, so the result was 
insignificant leading to the acceptance of the null hypothesis. This result means the respondents' religiosity level do not have a significant bearing on their spirituality. This result contradicts the study of Ocampo et al. (2013) and Batara (2015) that religiosity and spirituality are overlapping concepts (or closely related ideas) and correlate with each other. However, it was also stressed out that "age differences" could be one of the factors of difference by which this study admitted as its limitation.

Table 11. Relationship between religiosity and life satisfaction

\begin{tabular}{|c|c|c|c|c|c|}
\hline $\begin{array}{c}\text { Pearson } \mathbf{r} \\
\text { value }\end{array}$ & $\begin{array}{c}\text { Critical } \\
\text { Value of } \mathbf{r}\end{array}$ & Df & $\begin{array}{c}\text { Level of } \\
\text { significance }\end{array}$ & Result & Decision \\
\hline 0.1648 & 0.5139 & 13 & 0.05 & Insignificant & Ho: Accept \\
\hline
\end{tabular}

Correlation of Religiosity and Life Satisfaction. This study found out that religiosity had no significant relationship with the respondents' life satisfaction status. This was proven through the Pearson computation of the two variables where the $r$ value $(0.1648)$ was lower than the critical value at $13 \mathrm{df}$ and 0.05 level of significance. The result was not significant; hence, the decision was to accept the null hypothesis. This means the respondents' level of religiosity was not significantly related to their perceived life satisfaction.

The result is parallel with Kortt, Dollery, and Grant's (2015) findings in their study on the residents of Eastern Germany by which they found no trace of correlation between religiosity and life satisfaction. However, in the Western part, they reported a positive correlation between the two variables. Kortt et al.'s findings in West Germany coincided with the study of Koenig, McCullough, and Larson (2001), Bergan and McConatha (2001) and Ellison, Gay, and Glass (1989) stressing the significant role of religion to a person's life satisfaction. Furthermore, Abdel-Khalek (2010) declared that the primary predictor of religiosity in his study was religious belief and life satisfaction.

Table 12. Relationship between spirituality and life satisfaction

\begin{tabular}{|c|c|c|c|c|c|}
\hline $\begin{array}{c}\text { Pearson } \mathbf{r} \\
\text { value }\end{array}$ & $\begin{array}{c}\text { Critical } \\
\text { Value of } \mathbf{r}\end{array}$ & Df & $\begin{array}{c}\text { Level of } \\
\text { significance }\end{array}$ & Result & Decision \\
\hline 0.67561 & 0.5139 & 13 & 0.05 & Significant & Ho: Reject \\
\hline
\end{tabular}

Correlation of Spirituality and Life Satisfaction. Spirituality and Life satisfaction in this study were found to be correlated after subjecting them 
to statistical treatment. The Pearson computation resulted in an $r$ value of 0.67561 which is greater than its critical value $(0.5139)$ at 0.05 level with 13 degrees of freedom; hence the result is significant leading to the rejection of the null hypothesis. It suggests that the respondents' "search for God" influenced their perception about life.

This result coincided with the study of Karakaas (2010) and Ivtzan, Chan, Gardner, \& Prashar, (2013) on the important impact of one's spirituality on one's psychological well-being. Moreover, this study found support in Habib, Riaz, \& Akram's (2012) study where they demonstrated the significant effect of spirituality on a person's life satisfaction. It coincides with Newport's (2006) postulation that highly spiritual people were more likely to feel a high level of happiness than those with low spirituality.

Interestingly, this study is also confluent with he findings of an Cappellen and colleagues that putting a value on one's spirituality has a relationship with experience of positive emotions (Van Cappellen et al., 2015) and positive emotions increase life satisfaction by building resilience (Cohn, 2009). Cohn's study stressed out that happy people feel satisfaction because they develop resources for living well (Cohn, 2009).

Table 13. Relationship between life satisfaction and service quality

\begin{tabular}{|c|c|c|c|c|c|}
\hline $\begin{array}{c}\text { Pearson } \mathbf{r} \\
\text { value }\end{array}$ & $\begin{array}{c}\text { Critical } \\
\text { Value of } \mathbf{r}\end{array}$ & Df & $\begin{array}{c}\text { Level of } \\
\text { significance }\end{array}$ & Result & Decision \\
\hline 0.251601 & 0.5139 & 13 & 0.05 & Insignificant & Ho: Accept \\
\hline
\end{tabular}

Correlation of Life Satisfaction and Service Quality. Life Satisfaction and Service Quality were not correlated as demonstrated through the Pearson Moment Correlation Coefficient. It yielded an $r$ value of 0.251601 lower than the critical value of $r$ at $13 \mathrm{df}$ and 0.05 confidence level which is 0.5139; hence, the result was insignificant. The decision was to accept the null hypothesis, so there was no significant correlation between the two mentioned variables. It implied that life satisfaction had no bearing on the respondents' service quality.

The result of this study contradicted previous researchers (Duckworth Quinn, and Seligman, 2009) who showed the correlation between life satisfaction and work performance. In the research of Duckworth et al. (2009), life satisfaction along with other factors predicts teacher effectiveness. It revealed that satisfied teachers outperformed their coteachers who have poor life satisfaction. 
Table 14. Relationship between religiosity and service quality

\begin{tabular}{|c|c|c|c|c|c|}
\hline $\begin{array}{c}\text { Pearson } \mathbf{r} \\
\text { value }\end{array}$ & $\begin{array}{c}\text { Critical } \\
\text { Value of } \mathbf{r}\end{array}$ & Df & $\begin{array}{c}\text { Level of } \\
\text { significance }\end{array}$ & Result & Decision \\
\hline 0.410974 & 0.5139 & 13 & 0.05 & Insignificant & Ho: Accept \\
\hline
\end{tabular}

Correlation of Religiosity and Service Quality. The table 14 shows that the Pearson $r$ value of 0.410974 was lesser than its critical value of 0.5139 at $13 \mathrm{df}$ at 0.05 level of significance, thus, the result is insignificant. It led to the acceptance of the null hypothesis which means there was no significant relationship between the two variables. Although the respondents were highly religious, it did not affect how they serve their customers (i.e., students).

This study failed to validate the assumption that high religiosity was a reliable assurance for excellent performance. As revealed, the respondents' religious fervency did not statistically color their service quality. Such result contradicts the philosophical thought that "religiosity moves workers from being self-centered to being mission-oriented or being concerned with other's welfare (Lanfer, 2006). It can be deduced from this result that religiosity is no guarantee of quality service. This is probably due to their failure to assimilate the basic tenets of Christianity (e.g., selfless service, integrity, and commitment) to one's work values and orientation.

Table 15. Relationship between spirituality and service quality

\begin{tabular}{|c|c|c|c|c|c|}
\hline $\begin{array}{c}\text { Pearson } \mathbf{r} \\
\text { value }\end{array}$ & $\begin{array}{c}\text { Critical } \\
\text { Value of } \mathbf{r}\end{array}$ & Df & $\begin{array}{c}\text { Level of } \\
\text { significance }\end{array}$ & Result & Decision \\
\hline 0.307424 & 0.5139 & 13 & 0.05 & Insignificant & Ho: Accept \\
\hline
\end{tabular}

Correlation of Spirituality and Service Quality. Spirituality and Service Quality were not significantly proven to be correlated in this study. The Pearson computation resulted in an $r$ value of 0.307424 which waslesser than its critical value $(0.5139)$ at $13 \mathrm{df}$ with 0.05 level of significance; hence the result was insignificant and led to the acceptance of the null hypothesis. As depicted previously, the respondents were very spiritual, yet their service quality fell at the satisfactory level only. It implies that one's spirituality is also not a guarantee of having excellent service quality.

The result is opposite to the findings of Osman-Gani et al. (2010) who identified religiosity and spirituality as variables affecting employees' 
performance in an organization and Soobaroyen and Jayasinghe (2007) who stressed out the positive role of spirituality to personal values and behavior towards work. In their study, spirituality tainted the respondents' work performance. However, among CNHS faculty, the opposite was true. The researchers assumed this result was due to lack of spiritual assimilation of the basic tenets of Christianity by which social responsibility resides. However, it does not mean that they do not possess zeal and commitment in their work; as humans, they also err due to factors (e.g., class interruptions, hectic schedule) that are beyond their control but their passion to serve are not really quenching. Their fervency to teach is still apparent based on their satisfactory performance shown.

\section{CONCLUSION}

Based on the results and findings, the following salient points were drawn:

1. The respondents were highly religious in general and in four areas of religiosity, such as, ideology, public practice, private practice, and religious experience. The high religiosity level of the respondents indicated that they were very active in their religious lives.

2. They possessed High Spirituality level and felt that they were "Very Close" to God. They also obtained Average Satisfaction in life as measured in the SWLS.

3. The respondents showed a satisfactory level of service quality in the five areas of service quality (Reliability, Assurance, Tangibles, Empathy, and Responsiveness). However, the respondents obtained an unsatisfactory rating in one of the items in the reliability dimension which talked about finishing the required competencies for every quarter.

4. There was a correlation between the respondents' spirituality and life satisfaction.

5. It was found out that religiosity, spirituality and life satisfaction are not predictors of teachers' service quality. Since there was no correlation among these variables to how the teachers serve their students, the burden of this study rests on how to utilize these attributes to the advantage of the respondents as well as the whole community. 


\section{RECOMMENDATIONS}

Basing upon the findings of the study, the researchers recommend the following:

1. Enhance the respondents' religiosity, spirituality and life satisfaction through religious seminars/retreats/recollections.

2. Raise their religious intellectual dimensions by reading books (e.g., catechism), about their doctrines and practices.

3. Pursue personality enhancement training to maintain and optimize the teachers' positive attitudes.

4. Undertake advanced planning by making a flexible competency calendar to minimize waste of time.

5. Conduct stress debriefing seminars and team building activities every end of the school year to empower teachers' ability to transcend with life's challenges and connect with others.

6. Implement enhancement program that translate the high religiosity and spirituality levels of the respondents into selfless service and commitment.

\section{REFERENCES CITED}

Abad, R. G. (2001). Religion in the Philippines. Philippine Studies, 49(3), 337-367. Retrieved from https://goo.gl/oXKfmv (accessed last 15 November 2015).

Abdel-Khalek, A. M. (2010). Religiosity, subjective well-being, and neuroticism. Mental Health, Religion and Culture, 13(1), 67-79. Retrieved from http://goo.gl/FOOLWu (accessed last 18 February 2016).

Batara, J. B. L. (2015). Overlap of religiosity and spirituality among Filipinos and its implications towards religious prosociality. International Journal of Research Studies in Psychology, 4(3). Retrieved from http://goo.gl/ xevDhG (accessed 15 November 2015). 
Batara, J. B. L. (2015). Religious song as a facilitator of prosocial behavior. International Journal of Research Studies in Psychology, 5(1). Retrieved from http://goo.gl/kNuVhK (accessed last 7 April 2016).

Bergan, A., \& McConatha, J. T. (2001). Religiosity and life satisfaction. Activities, Adaptation \& Aging, 24(3), 23-34. Retrieved from https://goo.gl/xQKcGr (accessed last 15 February 2016).

Blando, J. A. (2006). Spirituality, religion, and counseling. Counseling and Human Development, 39(2), 1. Retrieved from https://goo.gl/Avvydr (accessed last 15 February 2016).

Buck, H. G. (2006). Spirituality: concept analysis and model development. Holistic Nursing Practice, 20(6), 288-292. Retrieved from https://goo.gl/7sMM4L (accessed last 15 February 2016).

Casiño, T. C. Mission in the Context of Filipino Folk Spirituality: Bahala na as a Case in Point. Mission Spirituality and Authentic Discipleship (Seoul, 2009), 83-96. Retrieved from http://goo.gl/L2y32P (accessed last 18 October 2015).

Cohn, M. A., Fredrickson, B. L., Brown, S. L., Mikels, J. A., \& Conway, A. M. (2009). Happiness unpacked: positive emotions increase life satisfaction by building resilience. Emotion, 9(3), 361. Retrieved from https://goo.gl/ARpWzo (accessed last 30 January 2016).

Diener, E. (2000). Subjective well-being: The science of happiness and a proposal for a national index (Vol. 55, No. 1, p. 34). American Psychological Association. Retrieved from http://goo.gl/uPaZcv (accessed last 10 November 2015).

Diener, E., \& Diener, C. (1996). Most people are happy. Psychological science, 7(3), 181-185. Retrieved from http://goo.gl/8r7j2q (accessed last 15 February 2016).

Diener, E., Diener, M., \& Diener, C. (1995). Factors predicting the subjective well-being of nations. Journal of personality and social psychology, 69(5), 851. Retrieved from https://goo.gl/N2nPTL 
(accessed last 8 February 2016)

Diener, E., Emmons, R.A., Larson, R.J., \& Griffin, . (1985). The Satisfaction with Life Scale. Journal of Personality Assessment, 49, 71-75. Retrieved from http://goo.gl/tv0jWQ (accessed last 14 February 2016).

Duckworth, A. L., Quinn, P. D., \& Seligman, M. E. P. 2009. Positive predictors of teacher effectiveness. Journal of Positive Psychology, 4: 540-547. Retrieved from http://goo.gl/szZjwx (accessed last 17 February 2016)

Durban, J. M., \& Catalan, R. D. (2012). Issues and Concerns of Philippine Education Through the Years. Issues, 1(2). Retrieved from http://goo. gl/Zv7kD6 (accessed last 10 August 2015).

Education For All (EFA) Global Monitoring Report 2005. Retrieved from https://goo.gl/WzoSsf (accessed last 18 February 2016).

Education for All 2015 National Review Report: Philippines. Retrieved from https://goo.gl/wtjATS (accessed last 18 February 2016).

Ellison, C. G., Gay, D. A., \& Glass, T. A. (1989). Does religious commitment contribute to individual life satisfaction?. Social forces, 68(1), 100-123. Retrieved from https://goo.gl/3LMrgL (accessed last 18 February 2016).

Figer, R. C., \& Ynion, W. L. G. (2010). Religiosity Online: Holy Connections with the Homeland by Filipino Migrants in Japan. Asian Social Science, 6(2), 3. Retrieved from http://goo.gl/JRI6PL (accessed last 13 February 2016).

Fisher, J. (2010). Development and application of a spiritual well-being questionnaire called SHALOM.Religions, 1(1),105-121.Retrieved from http://goo.gl/RxDKe0 (accessed last 14 November 2015).

Fryback, P. B., \& Reinert, B. R. (1999, January). Spirituality and people with Poetentially fatal diagnoses. In Nursing forum (Vol. 34, No. 1, pp. 13-22). Blackwell Publishing Ltd. Retrieved from https://goo.gl/x7Su4x (accessed last 8 February 2016). 
George, L. K., Larson, D. B., Koenig, H. G., \& McCullough, M. E. (2000). Spirituality and health: What we know, what we need to know. Journal of social and clinical psychology, 19(1), 102-116. Retrieved from http:// goo.gl/aJy5Tu (accessed last 14 November 2015).

Guillory, W. A. (2001). The living organisation - spirituality in the workplace: A guide for adapting to the chaotically changing workplace (2nd ed.). Salt Lake City: Innovations International Inc.

Habib, S., Riaz, M. N., \& Akram, M. (2012). Emotional Intelligence as Predictor of Life Satisfaction among Nurses: Mediating Role of Spiritual Wellness. FWU Journal of Social Sciences, 6(1), 73. Retrieved from http://goo.gl/yCioqC (accessed last 18 October 2015).

Hanushek, E. A., \& Rivkin, S. G. (2007). Pay, working conditions, and teacher quality. The future of children, 69-86. Retrieved from https:// goo.gl/4HyK8y (accessed last 8 February 2016).

Hightower, A. M., Delgado, R. C., Lloyd, S. C., Wittenstein, R., Sellers, K., \& Swanson, C. B. (2011). Improving Student Learning By Supporting Quality Teaching. Retrieved from http://goo.gl/eGE5Fx (accessed last 8 February 2016)

Holdcroft, B. (2006). What Is Religiosity? Catholic Education: A Journal of Inquiry and Practice, 10(1), 89-103. Retrieved from http://goo.gl/ VQYNgk (accessed last 15 November 2015).

Huber, S., \& Huber, O. W. (2012). The centrality of religiosity scale (CRS). Religions, 3(3), 710-724. Retrieved from https://goo.gl/nxbp4E (accessed last 5 February 2016).

Incheon Declaration. (2015). Retrieved February 15, 2016, from http://goo. gl/T7KI5u, (accessed last 15 February 2016).

Ivtzan, I., Chan, C. P., Gardner, H. E., \& Prashar, K. (2013). Linking religion and spirituality with psychological well-being: Examining selfactualisation, meaning in life, and personal growth initiative. Journal of Religion and Health,52(3), 915-929. Retrieved from http://goo.gl/ IIGyNh (accessed last 5 February 2016). 
Jaafar, J. L. S. B., \& McCarthy, S. (Eds.). (2009). Building Asian Families and Communities in the 21st Century: Selected Proceeds of the 2nd Asian Psychological Association Conference, Kuala Lumpur, Malaysia, June, 2008. Cambridge Scholars Publishing. Retrieved from https:// goo.gl/Cemfpd (accessed last 15 February 2016).

Jocano, F.L. (1967). Filipino Catholicism: A case study in religious change. Retrieved from http://goo.gl/AAW4xX, (accessed last 15 February 2016).

Karakas, F. (2010). Spirituality and performance in organizations: A literature review. Journal of business ethics, 94(1), 89-106. Retrieved from https://goo.gl/fkBgBq, (accessed last 17 February 2016)

Koenig, H. G. (2012). Religion, spirituality, and health: The research and clinical implications. ISRN psychiatry, 2012. Retrieved from https://goo. gl/AcMsw4 (accessed last 15 November 2015).

Koenig, H. G. (2012). Religion, spirituality, and health: The research and clinical implications. ISRN psychiatry, 2012. Retrieved from http://goo. gl/j1o0m5 (accessed last 15 November 2015).

Kortt, M. A., Dollery, B., \& Grant, B. (2015). Religion and life satisfaction down under. Journal of Happiness Studies, 16(2), 277-293. Retrieved from https://goo.gl/QIz2DV (accessed last 16 February 2016).

Lanfer, S. G. (2006). Believing at work: Modeling the interplay of religious faith and business (Doctoral dissertation, Massachusetts Institute of Technology). Retrieved from https://goo.gl/ZTfvbq (accessed last 2 February 2016).

Magno, C. (2007). The role of teacher efficacy and characteristics on teaching effectiveness, performance, and use of learner-centered practices.The Asia Pacific Education Researcher, 16(1). Retrieved from http://goo.gl/u6vB06 (accessed 23 February 2016). 
McCaffrey, J. R., Lockwood, D. F., Koretz, D. M., \& Hamilton, L. S. (2003). Evaluating value added models for teacher accountability [Monograph]. Santa Monica, CA: RAND Corporation. Retrieved from http://goo.gl/ i65Z5G (accessed last 19 January 2016).

Miller, W. R. and J. E. Martin 1988. Spirituality and behavioral psychology: Toward integration. In Behavior therapy and religion: Integrating spiritual and behavioral approaches to change, edited by W. R. Miller and J. E. Martin, 13-23. Newbury Park, CA: Sage.

Newport, F. (2006). Religion most important to Blacks, Women, and Americans. Retrieved from https://goo.gl/DPykQ1 (accessed last 11 November 2015).

Nickles, T. (2011). The role of religion and spirituality in counseling (Doctoral dissertation, California Polytechnic State University, San Luis Obispo). Retrieved from http://goo.gl/TOz2ld (accessed last 11 November 2015).

Ocampo, A. C., Mansukhani, R., Mangrobang, B., \& Juan, A. M. (2013). Influences and perceived impact of spirituality on Filipino adolescents. Philippine Journal of Psychology, 46(1), 89-113.

Osman-Gani, A. M., Hashim, J., \& Ismail, Y. (2010). Effects of religiosity, spirituality, and personal values on employee performance: A Conceptual Analysis. Retrieved from http://goo.gl/6u5tRo (accessed last 10 February 2016).

Parasuraman, A., Zeithaml, V. A., \& Berry, L. L. (1985). A conceptual model of service quality and its implications for future research. the Journal of Marketing, 41-50. Retrieved from https://goo.gl/oJFP6e (accessed last 14 February 2016)

Pe-Pua, R., \& Protacio-Marcelino, E. A. (2000). Sikolohiyang Pilipino (Filipino psychology): A legacy of Virgilio G. Enriquez. Asian Journal of Social Psychology, 3(1), 49-71. Retrieved from http://goo.gl/1wtZtQ (accessed last 30 January 2016) 
Piedmont, R. L. (2007). Cross-cultural generalizability of the Spiritual Transcendence Scale to the Philippines: Spirituality as a human universal. Mental Health, Religion \& Culture, 10(2), 89-107. Retrieved from https://goo.gl/xzmydk (accessed last 17 February 2016)

"Religion." Merriam-Webster.com. Merriam-Webster, n.d. Web. 14 Nov. 2015.

Rigor, Garie (2015). Passion for Quality Education. Retrieved from https:// goo.gl/1iJpa2, (accessed last 17 February 2016).

Russell, J. (2007). An Evaluation of the Importance of Viktor Frankl for the Psychology of Religion. Retrieved from http://goo.gl/KvaUni, (accessed last 15 February 2016).

Ryan, M. (2006). Religious education in Catholic schools: An introduction for Australian students. Melbourne: David Lovell Publishing.

Soobaroyen, T. \& Jayasinghe,K. (2009)"Religious "spirit" and peoplesperceptions of accountability in Hindu and Buddhist religious organizations", Accounting, Auditing \& Accountability Journal Vol. 22 No. 7, pp. 997-1028.

Stark, R., \& Glock, C. Y. (1968). American piety, patterns of religious commitment. Retrieved from https://goo.gl/uHnS6T (accessed last 14 February 2016).

Tigno, J. (2007). Serialized Filipino identity in Japan. Paper presented at The Osaka University Global Collaboration Center, July 27 . Retrieved from http://goo.gl/5QfbGy (accessed last 13 February 2016).

Underwood, L. G., \& Teresi, J. A. (2002). The daily spiritual experience scale: Development, theoretical description, reliability, exploratory factor analysis, and preliminary construct validity using health-related data. Annals of Behavioral Medicine, 24(1), 22-33. Retrieved from https://goo.gl/BN2eFp (accessed last 13 February 2016). 
Usop, A. M., Askandar, D. K., Langguyuan-Kadtong, M., \& Usop, D. A. S. O. (2013). Work performance and job satisfaction among teachers. Int. J. Humanit. Soc. Sci, 3, 245-252. Retrieved from http://goo.gl/wWGK4L (accessed last 14 February 2016)

Van Cappellen, P., Toth-Gauthier, M., Saroglou, V., \& Fredrickson, B. L. (2015). Religion and well-being: The mediating role of positive emotions.Journal of Happiness Studies, 1-21. Retrieved from http:// goo.gl/T8qc82 (accessed last 8 February 2016)

VSO (2002) What makes teachers tick? A policy research report on teachers' motivation in developing countries. London: Voluntary Service Overseas (VSO).

World Education Forum 2015. (2015). Retrieved from http://goo.gl/bzG6x9 (accessed last 15 February 2016).

Yalung, C. A. (2010). The Contribution and Influence of Spirituality and Religion on Filipino Caregivers' Motivations and Services (Doctoral Dissertation, California State University, Sacramento). Retrieved from http://goo.gl/UFGHri (accessed last 16 April 2016).

Zeithaml, V. A., Parasuraman, A., \& Berry, L. L. (1990). Delivering quality service: Balancing customer perceptions and expectations. Simon and Schuster. 